\title{
A Framework on Internet Banking Services for the Rationalized Generations
}

\author{
Md. Rahimullah Miah
}

Lecturer in MIS, Leading University, Sylhet, Bangladesh

\begin{abstract}
The augmented Internet Banking Service is increasingly popular both in Bangladesh and elsewhere. This paper explores a predicted framework for global Internet Banking that emphasizes the transformative interaction among the effective customers around the regional, national and global banking indicating advanced on backend models, instructional strategies, and transaction technologies in the context on upcoming generations. We have to develop the framework on global enhanced transaction systems especially individual global account, effective online banking systems to fulfill the required method, implementing design and appraising the feedback with standard technology according to network topology for disseminating of global banking technological arena. Despite decades of development, electronic payments still need practical examples of how to use electronic payment technology within a uniqueness and rationalized way including global electronic transaction, language tools, currency converter and electronic workstation. This research focuses the major issues responsible for Internet Banking based on respondents' perception through various internet applications. The author presents a theoretical framework for our represented method, taking into account previous models and characteristics of an effective Internet Banking Security. In addition, we illustrate the global technology that we have to expand and execute among the customers' satisfaction within the expected model. We follow this with an evaluation of achievement, both in the global banking implementation and the amplitude framework according to periodical requirements. Finally, we focus highly developed research trajectories of the model and recommendations for how to further avail the internet banking subscribers to design more secure alternatives.
\end{abstract}

Key words: Internet Banking, Currency Converter, Perception, Rationalized and Technological Arena JEL Classification Code: G29

\section{INTRODUCTION}

$\mathrm{I}$ nternet Internet banking is the term used for new generations in up-to-the-minute banking system which is also named as online banking or electronic banking and it is an outgrowth of computer and mobile banking. This type of banking utilizes the internet as the delivery channels by which to carry out banking activities globally and nationally, viz. transferring electronic funds, paying bills, viewing checking and savings account balances, paying mortgages and purchasing financial instruments, certificates of deposits [11], share market, PayPal and so on relevant phenomena. Internet banking is a consequence of explored possibility to use internet function in one of the various domains of general and electronic commerce. This is complicated to conjecture whether the internet tools, techniques, software, hardware and appliance have been applied for expediency of bankers or for the customers' convenience. But eventually it makes a payment in increasing the efficiency of the banking operation as well providing more convenience to customers involving social media with updates technological arena. As a result, there are more interacting among bankers, specialist, engineers and customers' transact from one corner of the country to another corner. Worldwide internet entrance exceeded 1018 million people till to 2005 [14], contributing new banking markets like e-commerce \& e-business for internet-based services such as internet banking has practiced unstable growth in many countries and has transformed traditional banking practices as a whole. By update offering internet banking services, the traditional financial organizations seek to inferior operational costs, get better consumer banking services, maintain prompt consumers and enlarge share of customers. Recent evidence proposes that an internet-based consumers banking approach may be effective with more profitable, promptly, trustworthy and committed consumers compared with traditional banking consumers [1]; [5] to follow just in time. Thus, smart banks now regard the internet channel as equally important to traditional channels of branches, automated teller machines (ATM), telephone banking, call money and call centres (Gartner 2003a). In the update banking environment, internet banking is gradually more managed as an operational activity and a vital constituent of a multi-channel strategy [4]. The Internet Banking creates more advanced and rationalized for the present and future generations 
Asian Business Review, Volume 3, Number 4/2013 (Issue 6)

ISSN 2304-2613 (Print); ISSN 2305-8730 (Online)

not only economy but electronic exchangeability also.

\section{CONTEXT OF INTERNET BANKING SERVICES IN BANGLADESH FOR tHe RATIONALIZED GENERATIONS}

Bangladesh is a developing country where a large number of populations are led including less number of internet users mentioning about 750000 users of total populations including about $5 \%$ people are used internet in the year 2011, meanwhile $3.7 \%$ in $2010,3.1 \%$ in 2009 and $2.5 \%$ in 2008 respectively which is increased in subsequent year gradually [22]. On the other hand, Internet Banking users are less than internet users successively according to the availability, accessibility, propinquity of user's requirements and relevant demanded networks. Notwithstanding the considerable dissemination of consumer internet banking in many countries to date, banks seek further market growth. Presently, traditional market growth trends are uncertain, time consuming and less customer satisfaction. We, all are bearing in mind the materialization of a society of persons, individuated utilization and new markets in the track for deep levels of consumer sustain [24], whose prerequisite relies on new strategies of customer relationship management and awareness management [10], and attention to the customer familiarity [18] searching to advocate the possibility that new influences on internet banking adoption may be at play for rationalized generations. Third, as the schooling of Lee and Colleagues [16] tinted, there is a need to explore consumer decision-making in internet banking adoption across a wide assortment of demographics, rather than focusing only on the division thought most likely to adopt - namely, the upper income demographic [3]. As internet banking is a relatively new concept in banking service delivery, another theory that may explain operative forces in consumer internet banking adoption is Rogers' theory of innovation diffusion [20]. It is [15] recognized the main individual needs for using the internet as community diversion, information, interactive control, and socialization and economic motivations. The TAM (Technology Acceptance Model) was developed by Davis [5] for the customer choices in internet banking adoption which is 'perceived usefulness' and 'perceived ease of use' for the manipulation in user's adoption of technologies. Consumer behavior in the adoption of internet banking may parallel aspects of online consumer behavior in common which are affected on the Knowledge of the internet gateway, expediency, stillness, perceived userfriendliness and effectiveness accordingly.

Table 1: Potential influences on customer adoption of internet banking [17].

\begin{tabular}{|c|c|}
\hline Rationalized patterns & Control options \\
\hline $\begin{array}{l}\text { a) Technology } \\
\text { Recognition }\end{array}$ & (i) Perceived helpfulness parameters, (ii) Perceived ease of use technology \\
\hline $\begin{array}{l}\text { b) Adoption of } \\
\text { Internet Banking }\end{array}$ & $\begin{array}{l}\text { (i) Convenience option, (ii) Service quality and quantity, (iii) Perceived relative advantage, (iv) } \\
\text { Compatibility, (v) Trainability and complexity, (vi) Demographics, consumer attitudes and } \\
\text { beliefs, (vii) Security, privacy, trust, risk, (viii) Needs already satisfied, familiarity, habit. (ix) } \\
\text { Lack of relevant awareness, (x) Consumer, product and organization, (xi) Channel } \\
\text { characteristics, (xii) Malleability, (xiii) Computer and technology combination, (xiv) Confidence, } \\
\text { knowledge work, (xv) High levels of internet use at work, (xvi) Gender parity. }\end{array}$ \\
\hline $\begin{array}{l}\text { c) Function to mass } \\
\text { media use: Prospective } \\
\text { gratification }\end{array}$ & $\begin{array}{l}\text { (i)Custom strength and workability, (ii) Underprovided self-regulations, (iii) Self-efficacy and } \\
\text { actuality }\end{array}$ \\
\hline $\begin{array}{l}\text { d) Transmission of } \\
\text { innovation }\end{array}$ & $\begin{array}{l}\text { (i) Relative improvement, (ii) Compatibility, (iii) Complication, (iv) Treatability, (v) } \\
\text { Observability }\end{array}$ \\
\hline $\begin{array}{l}\text { e) Function to mass } \\
\text { media use: Uses and } \\
\text { gratifications }\end{array}$ & $\begin{array}{l}\text { (i) Social diversion, (ii) information looking for, (iii) interactive control, (iv)socialization, (v) } \\
\text { Profitable motivations, (vi) Safety measures, privacy and trust }\end{array}$ \\
\hline $\begin{array}{l}\text { f) Service switching } \\
\text { costs }\end{array}$ & (i) Procedural pattern, (ii) Financial options, (iii)Relational entity \\
\hline $\begin{array}{l}\text { g) Online consumer } \\
\text { behavior and online } \\
\text { service adoption }\end{array}$ & $\begin{array}{l}\text { (i) Existing Familiarity, (ii) Channel knowledge, (iii) Cost effective, (iv) Convenience, (v) } \\
\text { Perceived accessibility, (vi) Perceived utility, (vii) Time savings, (viii) Site waiting time, (ix) } \\
\text { Security, privacy and expectation, (x) Service quality }\end{array}$ \\
\hline
\end{tabular}

Of these, convenience has increasingly been linked to online consumer choices. This is mentioned that in order to grow consumer internet banking demand, banks must make key enhancements that address customer concerns. Thus, it would behoove financial institutions to gain an understanding of the key factors that influence consumer internet banking adoption. This paper investigates the critical elements that shape the consumer decision to adopt internet banking for the rationalized generations which is the miraculous creation of modern technology

Copyright (C) 2012, Asian Business Consortium | ABR with the latest delivery channels for banking services. Bangladeshi banks are desperately embracing this new distribution channel to organize themselves for global business rivalry. Internet banking gets impetus over traditional banking due to this motto-'Any time banking, any place banking and any where banking for uniqueness rationalized users' forwarding present and update generations. Even though the potential, there are various factors such as security of internet transactions, technophobia, reluctance to change and preference for human interface 
which appear to impede the adoption of internet banking. Consequently these factors promoting or hampering the adoption have been the prime concern of this study. Bangladesh is now in an infancy stage of internet banking where $63 \%$ banks are on the online track and the 10 banks are in the verge of becoming online. [6]. It is a matter of joy that government has taken some mountainous steps to facilitate the internet banking by developing the regulatory environment and infrastructure. Internet banking enables customer to access his/her personal or business accounts anytime anywhere from home, office or when traveling. Through internet banking the customers can outlook his own account summary, third party transfer, paying bills, open/modify term deposit, loan repayments, statement request, cheque status inquiry, standing instructions, stop payment cheque, interest rate inquiry, foreign exchange rate inquiry, change password, letter of credit and bank guarantee. The Internet Banking is mounting popular day by day in Bangladesh tremendously. A number of private as well as local banks are departing online now considering the demand and necessity of fast banking [25] to the rationalized generations. Internet banking not only affords banking facility round the clock but also helps a country to get friendly to the international economy as well as business phenomena [3]. People throughout the world are now getting occupied with more activity and business and hence need the fast and anytime access and availability to his/her bank account as well as login user's options. Internet banking also makes possible buying, selling and relevant exchange various products which varies country to country and geographic locations now a days. At present 48 scheduled banks out of 60 banks are in Bangladesh but few banks have initiated Internet Banking systems viz. AB Bank Limited, Dutch Bangla Bank Limited, Janata Bank Limited, Bank Asia Limited, HSBC, City Bank Limited, BRAC Bank Limited, Jamuna Bank Limited, Southeast Bank Limited, Premier Bank Limited, First Security Bank Limited and others few govt. banks etc are taken in action already [3]. These are known as online banking to provide various services viz. the facility of account check, 24/7 banking access, transactions, statement print including query about cheque book information, internal fund transfer facility along with bill payment, mobile phone recharge, VISA card, loan account information, net-worth information, electronic transfer amongst accounts, personal information update, demand draft, ATM (Automated Teller Machine) info or PIN (Personal Identification Number) replacement request, cheque book order and so on [3].

\section{Methodology}

For the validation of above mentioned internet banking for rationalized generations, a research survey was conducted through questionnaire among four banks in
Sylhet City Corporation, viz. Dutch Bangla Bank Limited, Sonali Bank Limited, Pubali Bank Limited and Bangladesh Islami Bank Limited. Various methods were used among 24 respondents during the data collection period. These included observations, interviews and questionnaires. Semi-structured interviews were used and interviewees were selected based on the representation point of view and additionally in regard to their relevance to the conceptual questions. Additionally, different interviews were taking from the key informants of relevant administrative, analyst, professional and local users of the existing phenomena. In respect of resourceful materials of research in this paper mainly measured the references in the personnel and demo-official proceedings, published reports, newspapers, magazine, bulletin, souvenir, journals and various relevant institutions' reports to be related in internet banking technology. Secondly, some of the helpful literatures related to the topic in geographic area's written by well-known researchers have been taken to compare, cross and justify against the objectives. The above mentioned source-materials have been collected in government and private banks, and different university libraries etc in national and global geographic areas. We have also utilized modern technologies like internet, websites, email, mobile, telephone, skype, conferencing and networks etc. to collect facts and information about our research field which was helped us to reach a further more accurate decisions and opinions. Feedback meeting carried out in order to share the research findings with the respondents and staffs to get their feedback suggestions and comments of internet banking technology during the organized interview through questionnaires. The data were collected through field visit and secondary level. After collection the data were arranged, organized, sorted and assemblage according to research theme for compilation and analysis. All data were checked properly in order to find out their accuracy, by following the crossed checking method, i.e. checking the same information in different sources and verify the sources of information. This paper is the outcome of data sorting and assemblage through different relevant secondary information and field survey, which are carefully compiled and evaluated. Then the information were included preparation of data sheet and their manipulation into convenient forms used in the result and discussion section subsequently. Generally primary and secondary data were compiled with the renowned MS Excel and relevant software. After compilation of data/ information were analysed using standard data analysis softwares.

\section{THEORETICAL FRAMEWORK OF INTERNET BANKING FOR THE EFFECTIVE LOGIN}

This is imperative for different banks offering online banking to recognize the user innovativeness related to internet [21], intranet and extranet. It is also found that 
prior computer experience and expertise have indirect effect on perceptions of the users. [19]. InformationCommunication-Technology (ICT) and Accounting Information Systems (AIS) applications in the banking sectors gives competitive advantages to the banks by means of cost reduction, quick transaction, electronic fund transfer (EFT), electronic payment systems, wellorganized data management, analysis, safety, recovery management etc as well as it improves the competence of the users and trims down its traveling and waiting times and gives more independence on the priority of the theoretical framework for the rationalized generations. This framework tends to the users friendly not only national but also global including uniqueness login option's stalwarts within available internet accessibility interlinked with central bank to the global bank networks. The effective online banking framework systems fulfill the required methods, executing design and appraising the feedback with standard technology according to network topology for disseminating of global banking technological arena. The framework consists of core banking systems and outer banking systems including global server station. This global server station varies either in the figure 1 or it may be scalable according to periodical requirements. The core banking system implies national central bank and global central bank (proposed) interlinked with transaction indicating system security. The outer bank system includes presenting bank and remitting bank connecting with SWIFT/STN (Society for World Wide Inter-Bank Financial Telecommunication/ SWIFT Transport Network) including internet availability. Besides, login for customer services and operations tends to disseminating knowledge and relevant support on the means of verification and authentication for forwarding of electronic fund transfer (EFT) and payment system to the end user. However, all sorts of phenomena are providing internet connectivity with the gateway of global server station which is shown in the figure 1 as below. This framework occupies individual login globally and forward to the right customer of the right transaction within the right support through internet availability.

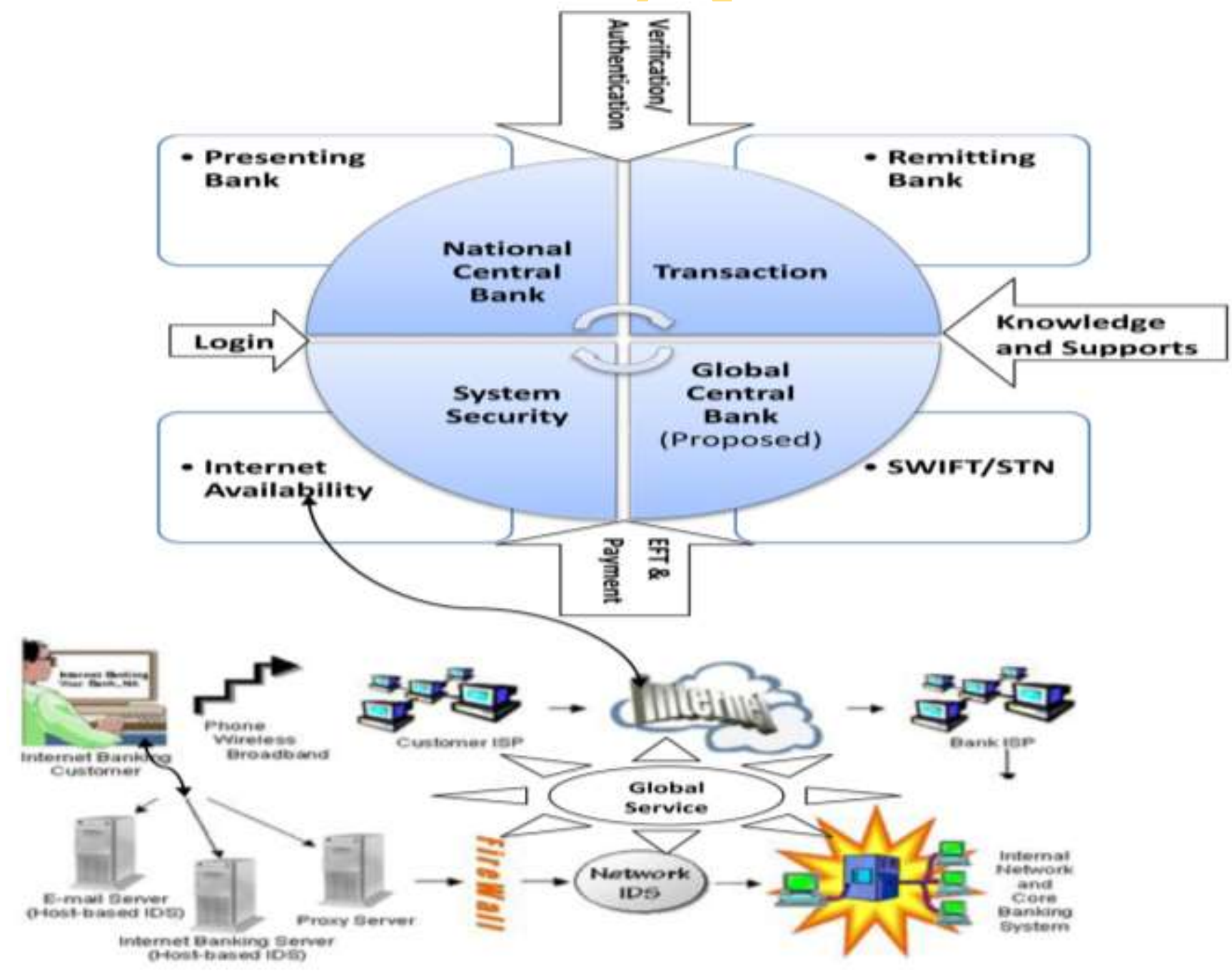

Figure1: A Framework on Global Internet Banking through unique login 


\section{FINDINGS}

\section{General summing up of the Survey Results}

The survey was organized among 24 respondents among four scheduled banks, viz. Dutch Bangla Bank Limited (DBBL), Sonali Bank Limited, Pubali Bank Limited and Bangladesh Islami Bank Limited (BIBL). The survey was conducted with different age gradation between 20 to above 60 years old. The maximum respondents indicated in the age 31 to 40 years among these banks where as lower respondents at above 60s which are shown in the figure 2. Bangladesh is a developing country which has lower internet users viz. India is the pioneer country in the subcontinent in $2011(10 \%)$ meanwhile Pakistan is the second most (above $8 \%$ ) as mentioned in the figure 3 . Internet Banking Users are increased day by day according to the figure 4 . The figure expressed that the maximum internet users is 5\% in 2011 while Internet Banking Users are above $2 \%$ in the same year. This value increased before the successive years. The expectation from the $65 \%$ respondent opined their opinion for expansion of Internet Banking tremendously not only national but also global wide. According to figure 5, we can assume that maximum agreed for expansion of Internet Banking.

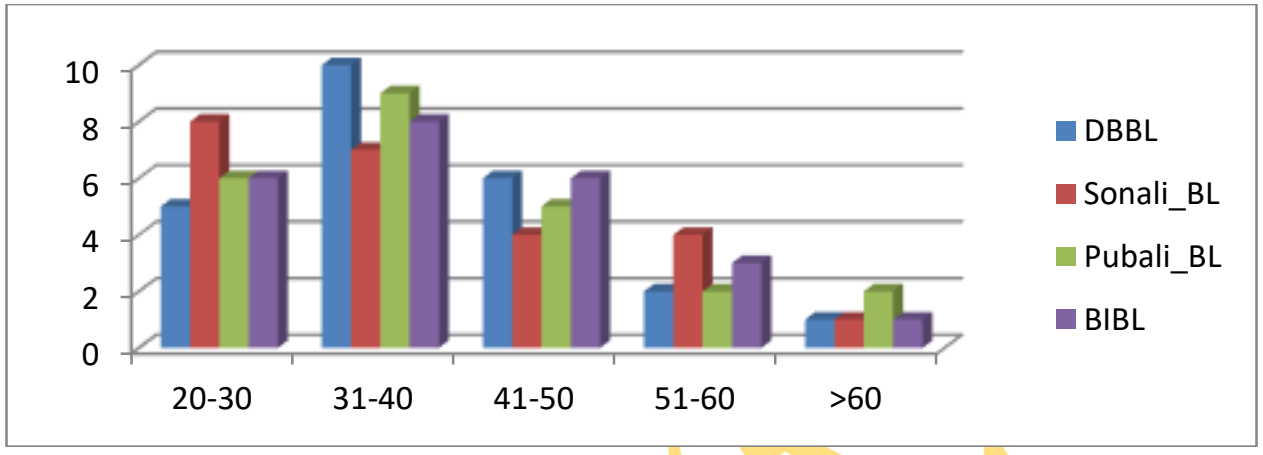

Fig-2: Age-gradation respondents Survey on Internet banking for reflection

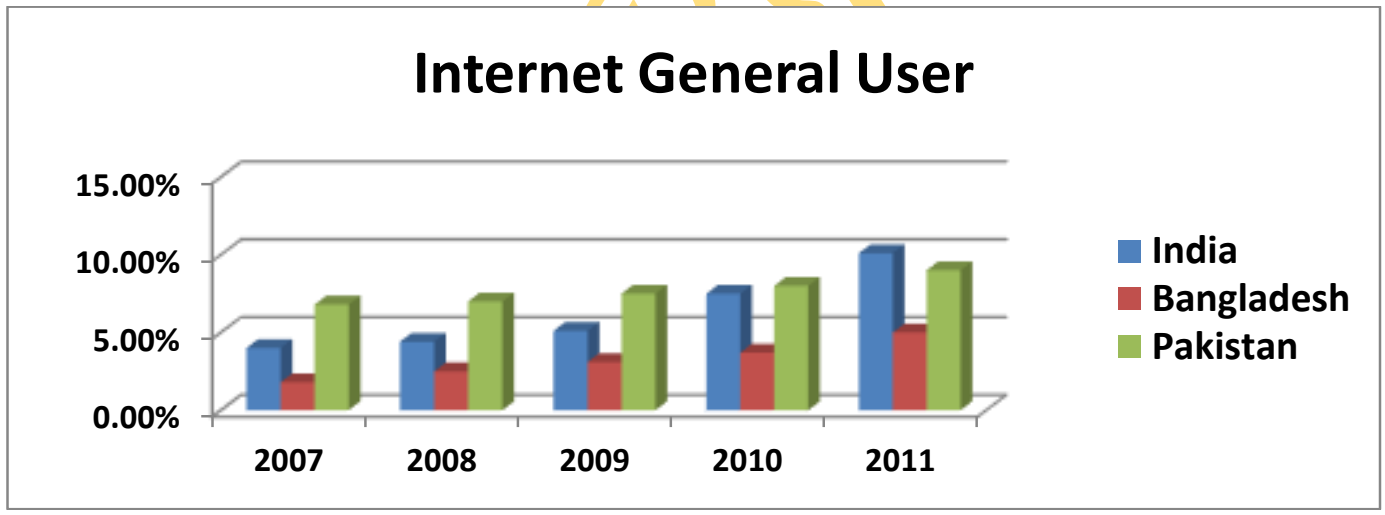

Figure 3: Comparative Study on Internet Users among India, Bangladesh and Pakistan

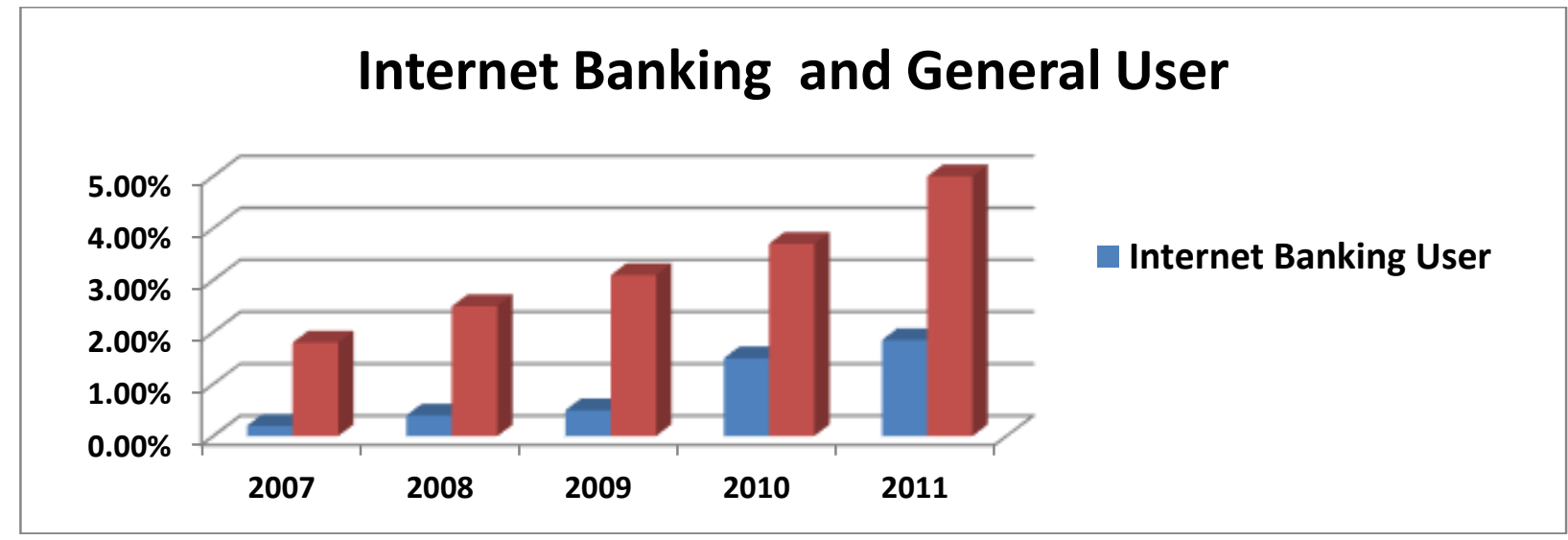

Figure 4: Comparison Study between Internet Banking Users and Internet General Users in Bangladesh 


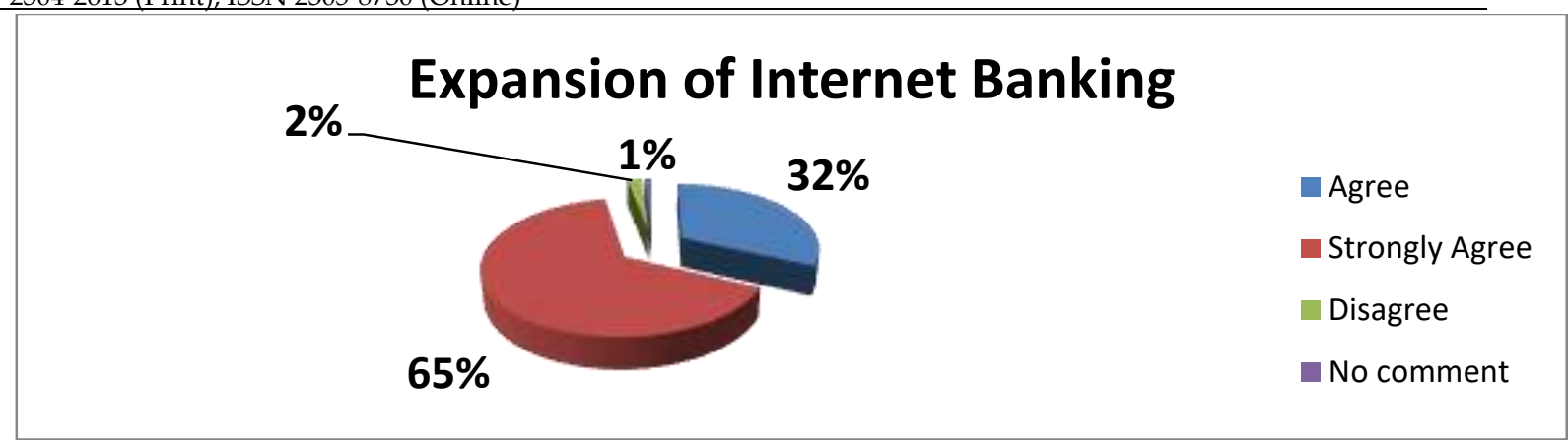

Figure 5: Expansion of Internet banking tremendously for modernized generations

\section{DISCUSSION}

Overall, the above discussion, we can harangue the respondents are rationalized aged-gradation indicating Internet General Users are increased gradually as well as Internet Banking Users in the same. However, we want to express that the scope of Internet Banking is increased day by day with update technological arena among the rationalized generations. General perception about internet banking was gauged by different items around the modern world. Out of which some items were related with convenience and flexibility and few items were related with transaction related benefits. All items were measured on a convenient scale. From the questionnaire convenience and flexibility related items clubbed together and average score taken to gauge the respondents' perception about convenience factor. Out of total respondents $65 \%$ respondents felt that internet banking is very convenient and flexible banking. And same percentage i.e. $65 \%$ from total users agrees or strongly agrees that internet banking is convenient. They felt that it gives benefits now queuing in bank and one can do anytime and anywhere banking. Approximately $32 \%$ percent of total respondent agreed that internet banking has transaction related benefits. These benefits include efficient and speedy transfer of funds with lower transaction cost. And, with internet banking one can check transaction details regularly without any hassle.

\section{Limitations AND FUtURE WORK}

Future sampling is suggested to be segmented in terms of demographic (age, sex, income, education etc) and geographical distribution on Internet banking networking systems. Equal Sample sizes should be selected and comparative study should be done. Although this research is primarily based on the primary data from the users and non users of Internet banking, the findings cannot be generalized, as the research is based on non probability sampling. This study has successfully examined the major factors responsible for internet banking based on respondents' perception on various internet applications; future research may include examined the banking transaction factors importance. Future research may also consider the impact of other demographic variable like banking education and else others.

\section{CONCLUSION}

User skill level could be a micro driver for the banks to devise their technological strategies. There is a lot of potential for the individuals to improve their Computer /Internet skills; hence there is tremendous opportunity for banks to go online. Therefore these kinds of solutions must be designed by considering individual skill levels. Online banking should not be very simple that it does not give value to highly skilled user and also it should not be so complicated so that the users with medium and Low level are unable to get benefits. Also trust and confidence of the user is inversely proportional to the level of complexity of the services. Online banking means today, web based banking. Today Banks are espousal web technology to offer more services at a cost effective rate within reduced. Although being late Bangladeshi scheduled banks put forward themselves to gain those competitive advantages. If the Government and Concerned Authority enhanced with tactics augmentation of global technology perfectly, it is not so far that Bangladesh will embrace the benefits of ICT in the full extent and get one of highest rates in the adoption of ICT as well as Internet Banking throughout the world. According to the world economy is increasing faster and banking sector is making smear each and every day spontaneously, Internet banking is very significant and effective to be a part of new technological arena. Bangladesh immediately started its expedition in internet banking and banks are coming forward to make it a triumph. Internet banking is clearly a huge benefit for the customers and saves a lot of time and things attain done so straightforwardly. Bangladesh, as a developing country can formulate the best out of Internet Banking and banks are completely augmented for rationalized generations.

\section{ACKNOWLEDGEMENT}

We are grateful to the Authority of Bangladesh Institute of Bank Management (BIBM), Dhaka in Bangladesh to progress this paper with indispensable and expert guidance, suggestions, constructive criticism, encouragement and inspiration throughout the paper presentation to the Annual Banking Conference. 


\section{REFERENCES}

[1] ABA (American Bankers Association). (2004). "Affluent Customers Going Online", ABA eAlert, IV (10), May 14, 2004. Retrieved from World Wide Web on 5 February 2006 at http:/ / www.aba.com/Industry+Issues/ealert410.htm

[2] ACNielsen, (2005) "Online banking continues despite security concerns", ACNielsen, Retrieved from World Wide Web on 7 February 2006 at http:/ / www.acnielsen.com.au/news.asp?newsID=301

[3] BankInfo, (2011). Internet Banking in Bangladesh. URL: http://bankinfobd.com/blog/internet-bankingin-bangladesh.

[4] Black, N.J., Lockett, A., Ennew, C., Winklhofer, H., and S. McKechnie, (2002). "Modeling customer choice of distribution channels: an illustration from financial services", International Journal of Bank Marketing, Vol. 20, No. 4: 161-173.

[5] Davis, F.D. (1989), "Perceived usefulness, perceived ease of use, and user acceptance of information technology", MIS Quarterly, Vol. 13 No. 3, pp. 319-40.

[6] Field Data. (2011). Internet Banking: A Study on Dutch Bangla Bank Limited, Sylhet Branch (unpublished Internship Report).

[7] Fox, S., (2005). "Online Banking Jumps 47\% in 2 Years", Pew Internet and American Life Project. Retrieved from World Wide Web on 15 February 2006 at http:/ / www.pewInternet.org/pdfs/PIP_Online_Bank ing_2005.pdf.

[8] Gartner, (2003a). "Gartner Says Banks Must Focus on Online Financial Applications to Remain Competitive in 2003 and Beyond", Press Release, Gartner Group, February 20, 2003.

[9] Gonzalez, M.E., M.R. Dentiste and M.W. Rhonda (2008). An Alternative Approach in Service Quality: An E-Banking Case Study. Quality Manage, 15: 41-48.

[10] Gebert, H., Geib, M., Kolbe, L. and W. Brenner, (2003). "Knowledge-enabled customer relationship management: integrating customer relationship management and knowledge management concepts", Journal of Knowledgedge Management, Vol. 7, No. 5: 107-123.

[11] Haque, Ahasanul; Ahmad Zaki Hj Ismail and Abu Hayat Daraz (2009). Issues of E-Banking Transaction: An Empirical Investigation on Malaysian Customers Perception. Journal of applied Sciences. (Retrived from www.ebsco.com on 20 March 2009)

[12] Heikki Karjaluoto, Minna Mattila and Tapio Pento (2002), "Factors underlying attitude formation towards online banking in Finland", International Journal of Bank Marketing, vol.20, No. 6, pp.261-272.
[13] IAMAI's Report on Online Banking 2006 Retrieved from http:/ / www.iamai.in/Research.aspx?Fileid=r8_home. htm\&rid $=8$

[14] IWS, Internet Usage Statistics, Internet World Stats, (2006). Retrieved from World Wide Web on 9 February 2006 http:/ / www.Internetworldstats.com/stats.htm.

[15] Korgaonkar, P.K and L.D. Wolin, (1999). "A multivariate analysis of Web usage", Journal of Advertising Research, Vol. 39, No. 2: 53-68.

[16] Lee, E-J., Kwon, K-N. and D.W. Schumann, (2005). "Segmenting the non-adopter category in the diffusion of Internet banking", International Journal of Bank Marketing, Vol. 23, No. 5: 414-437.

[17] Lichtenstein, Sharman \& Williamson, Kirsty (2006). Understanding Consumer Adoption of Internet Banking:An Interpretive Study in the Australian Banking Context. Journal of Electronic Commerce Research, VOL 7, NO.2, Pp. 50-66. URL: http:/ / www.csulb.edu/journals/jecr/issues/20062/p aper1.pdf

[18] O'Loughlin, D., Szmigin, I. and P. Turnbull, (2004). "From relationships to experiences in retail financial services", International Journal of Bank Marketing, Vol. 22, No. 7: 522-539.

[19] Petrus Guriting and Nelson Oly Ndubisi (2006), "Borneo online banking: evaluating customer perceptions and behavioral intention", Management research news, vol.29, No. 1/2, pp.6-15.

[20] Rogers, E.M., (1995). Diffusion of Innovations, 4th ed., The Free Press, New York, NY. USA.

[21] Walfried M. Lassar, Chris Manolis and Sharon s. Lassar (2004), "The relationship between consumer innovativeness, personal characteristics, and online banking adoption", International Journal of Bank Marketing, vol.23, No. 2, pp.176-199.

[22] WB(World Bank) (2012). IT.NET.USER.P2_Indicator_MetaData_en_EXCEL.

Website: api.worldbank.org/.../IT.NET.USER.P2_Indicator_MetaDa ta_en_EX.

[23] ZDNet, "Security worries holding back online banking", ZDNet UK, (2005). Retrieved from World Wide Web on 20 February 2006, URL: http:/ / news.zdnet.co.uk/Internet/security/0,3902037 5,39216740,00.htm.

[24] Zuboff, S. and Maxmin, J. (2003). The Support Economy, Viking.

[25] Online Banking. ( 2012). URL: http:/ / www.bangladeshbrandforum.com/magazine/ 042013/panorama.php 